\title{
研究展望 \\ 鉄道構造物のメンテナンス技術に関する研究開発の 現状と展望 \\ STATUS-QUO AND PERSPECTIVE OF RESEARCH AND DEVELOPMENT ON MAINTENANCE TECHNOLOGY \\ OF RAILWAY STRUCTURES
}

\author{
小西 真治 ${ }^{1}$ \\ Shinji KONISHI \\ 1 正会員 (財) 鉄道総合技術研究所 構造物技術研究部 部長 \\ (厂185-8540 国分寺市光町 2-8-38) \\ E-mail: konishi@rtri.or.jp
}

Key Words : maintenance, railway structures, inspection, monitoring

鉄道構造物は経年が百年を超えるものもあり, 旧式の構造物から最新の構造形式まで様々な年代の構造形式 が存在する．また，その種類も盛土，トンネル，橋梁など多岐にわたつており，メンテナンスの守備範囲は広 い. 鉄道では, 昭和 40 年ごろを境に防災投資の増加とともに，事後保全から予防・事後を組み合わせた効率的 な保全に変わり, 事故も減少した。しかし, 高度成長期に建設された大量の鉄道構造物の経年も 40 年を超えて きており，注意深くメンテナンスしなければならない対象構造物の量が加速度的に増加している。このような 背景をふまえ, まず, メンテナンスの変遷と現在の課題を述べ, 鉄道構造物維持管理標準を紹介する. 次に, 現 在の課題を解決するための最近の取り組みを紹介する. 最後に, メンテナンスについての今後の研究開発の展 望について述べる.

\section{1. はじめに}

約 130 年前に新橋〜横浜間に初めて鉄道が開通して から, 我が国では様々な種類の鉄道構造物が数多く建 設され，維持されてきた。 明治, 大正時代に作られた ものも多く, 中には経年が百年を超えるものも現役で 頑張っている。.また，高度成長期に建設された大量の 鉄道構造物の経年も 40 年〜 50 年を超えてきており, 注 意しなければならない構造物の量も加速度的に増加し ている。一方, 近年, 現場の技術継承の困難さや深刻 な労働力不足などの問題も浮上してきている. 鉄道需 要の飛躍的な増加が望めず，施設の改良や新設が困難 な現状では, 現在ある構造物を少ないリソースで効率 的にメンテナンスし, 安全の確保と構造物の長寿命化 を図っていくことが必要であり, 確実で効率的なメン テナンス手法の研究開発が望まれている.

このような背景をふまえ, 本稿では, 鉄道総合技術 研究所 (以降, 鉄道総研) が開発したあるいは開発中 のメンテナンス技術を中心に紹介するとともに, JR 各 社・民鉄における技術開発の取り組みについても一部 その概要を紹介し, 鉄道構造物のメンテナンスの変遷 と現在の課題，メンテナンスに関する研究開発の現状 と今後の展望について述べる.

\section{2. メンテナンスの変遷と現在の課題}

\section{（1）メンテナンスの変遷1)}

従前のメンテナンスの体系は, 何か問題が発生して から対処する，いわゆる事後保全であった．戦争中の 構造物の荒廃などから事故が多発するようになったが, 先輩たちの努力の末, 昭和 40 年頃を境に防災投資が増 加されるとともに，メンテナンスにおいても事後保全 から予防・事後を組み合わせた効率的な保全に変わっ た。これにより，災害件数が急激に減少する（図-1）と ともに事故も減少した. 昭和 48 年には取替え標準が制 定されたが, この体系は現在のメンテナンスの体系で あり，事前に定期的に検査を行って健全度判定を行い， 弱点箇所や変状箇所を抽出し詳細な検査を行い, 必要 な場合は措置（監視, 補修・補強等）を行うといった

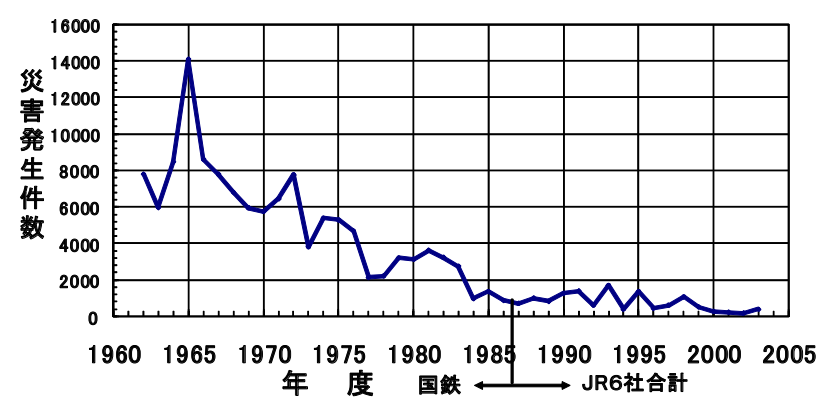

図-1 災害発生件数の減少 ${ }^{2)}$ へ加筆 
ものである.

その後, 昭和 50 年代には, 高性能なコンクリートや 耐候性鋼材などを用いるメンテナンスフリーの考え方 が生まれてきた。しかし，近年，コンクリートの中性 化やはく落の問題等が顕在化し, 小まめに調査し, 悪 いところに手を入れて使っていくことの大切さが見直 された。構造物は 100 年オーダーという長期にわたり 使用していくことからもメンテナンスフリーという考 え方を修正し，現在はミニマムメンテナンスという考 え方になっている。

\section{（2）メンテナンスの現在の課題}

図-2 に日本の鉄道橋梁下部工の数を示す。70 年を 超えるものが 3 万基, その 8 割はレンガ・ブロック積 みの下部工である。この図は平成 14 年に鉄道総研で 行ったアンケート調査結果（回収率 80\%）で，実態は このような構造物の数がもつと多いと考えられる。こ のように鉄道構造物のメンテナンスの特徵は,

1) 古いものから新しいものまで多岐にわたつている

2) 特に, 古い構造物が多く, 平均して経年が 50 年 を超えている

3) 橋梁, 橋脚, 擁壁, トンネル等, 様々な形式の構 造物，様々な材料による構造物が存在する

4) 量が多い

ことである。しかし，このように守備範囲が広いメン テナンスを限られた人員と予算で進めているのが現状 である。また，鉄道事業者の規模や経済的な条件から， メンテナンスの着眼点や方法のバラツキも見られる.

今後, 予想される人口減少や少子 ・高齢化による鉄 道利用者の減少, 鉄道現場における技術継承の困難さ ならびに深刻な労働力不足などを考えると，ますます 状況は厳しくなってくる.

このようなことから, 著者らは, 以下に示すものを メンテナンスの技術的な課題として研究開発を進めて いる.

1) 古い構造物のメンテナンス技術

2) 様々な形式の構造物のメンテナンス技術

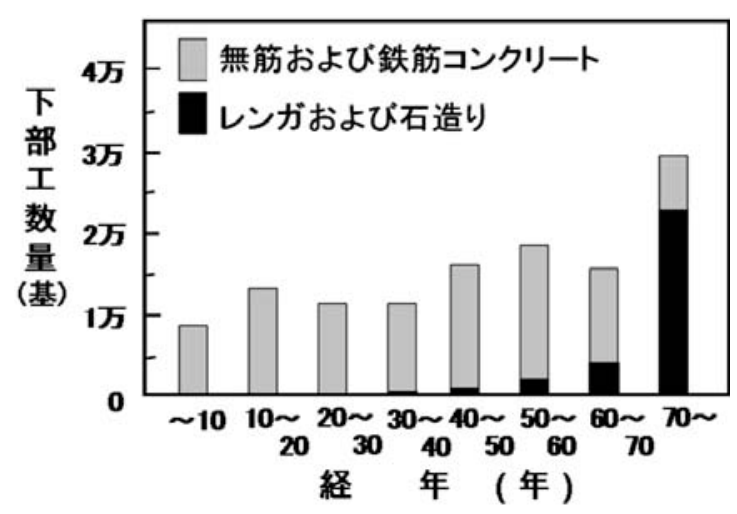

図-2 鉄道橋梁下部工の数量（平成 14 年)
3）常に，確実に危険な箇所が抽出できる技術

4) 少人数で大量の構造物がメンテナンスできる技術

5) バラツキのない健全度判定

6) 経済的な補修・補強方法

3 章以降, これらに関連した, 維持管理標準, 健全 度診断の自動化，検査の機械化，モニタリングシステ ム, 補修・補強工法の研究開発について述べる.

\section{3. 維持管理標準3),4)}

鉄道では施設等の検査方法や検査周期など維持管理 に関する技術基準として維持管理標準が国土交通省か ら平成 19 年 2 月に施行され, すべての鉄道事業者が同 じ体系でメンテナンスを行うことになった．鉄道総研 はこの標準の原案作成を国から受託し平成 12 年から次 の方針により検討を進めてきた。

1) 列車運行と旅客公衆の安全性を確保するための 性能照査型の体系を構築する

2) 幅広い技術レベルからなるすべての鉄道事業者 に適用できる体系とする

3) すべての構造物に共通する体系とする

4) これまでの維持管理体系を大きく変更しない

維持管理標準は, コンクリート構造物, 鋼・合成構 造物, 基礎 - 抗土圧構造物, 土構造物 (盛土・切土), トンネルの 5 編に分れ, それぞれ, 総則, 維持管理の 基本, 初回検査, 全般検査, 個別検査, 随時検査, 措 置, 記録, 付属資料といった構成になっている. 内容 としては,
1) 維持管理の性能規定化
2) 検査の区分
3) 検査の周期
4) 検査員
5) 調査項目と方法
6) 健全度判定
7) 措置
8) 記録

の考え方と方法が記載されている.

構造物では, 経年とともに低下する本体あるいは部 材の性能を継続して必要な水準以上に留めなければな らない。 そのため, 設計・施工時の配慮のほか適切な 維持管理を行うことが極めて重要になる．すなわち， 「設計・施工のみならず維持管理を含めて供用中の構造 物の性能をある水準以上に確保する」ことが性能規定 型の体系の基本的な考え方である.この性能を, 安全 性, 使用性, 復旧性の 3 つに区分し, 例えば, トンネ ルにおける性能項目に整理したものを表-1に示す。こ こで, 安全性は「列車が安全に走行するとともに落下 物等により周辺の人命が脅かされないための性能」に 
表-1 鉄道トンネルにおけろ要求性能と性能項目 ${ }^{4)}$

\begin{tabular}{|c|c|c|}
\hline $\begin{array}{l}\text { 要求 } \\
\text { 性能 }\end{array}$ & 性能項目 & 具体的な内容 \\
\hline \multirow{5}{*}{$\begin{array}{l}\text { 䓹 } \\
\text { 性 }\end{array}$} & $\begin{array}{l}1 \text { トンネル構造 } \\
\text { の安定性 }\end{array}$ & トンネルが崩壊しない. \\
\hline & $\begin{array}{l}2 \text { 建築限界外余 } \\
\text { 裕 }\end{array}$ & 建築限界を支障しない. \\
\hline & $\begin{array}{l}3 \text { 路盤部の安定 } \\
\text { 性 }\end{array}$ & $\begin{array}{l}\text { 列車の安全な運行に支障を与えるような路 } \\
\text { 盤の隆起・沈下・移動が生じない. }\end{array}$ \\
\hline & $\begin{array}{l}4 \text { はく落に対す } \\
\text { る安全性 }\end{array}$ & 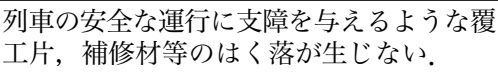 \\
\hline & $\begin{array}{l}5 \text { 漏水・凍結に } \\
\text { 対する安全性 }\end{array}$ & $\begin{array}{l}\text { 列車の安全な運行に支障を与えるような漏 } \\
\text { 水, 凍結が生じない. }\end{array}$ \\
\hline \multirow{3}{*}{$\begin{array}{l}\text { 使 } \\
\text { 角 }\end{array}$} & $\begin{array}{l}6 \text { 漏水・凍結に } \\
\text { 対する使用性 }\end{array}$ & $\begin{array}{l}\text { 漏水・凍結が坑内設備の機能に影響を及ぼ } \\
\text { さない. }\end{array}$ \\
\hline & 7 表面の污れ & $\begin{array}{l}\text { 検査に著しく支障を与えるような污れがな } \\
\text { い. }\end{array}$ \\
\hline & $\begin{array}{l}8 \text { 周辺環境に与 } \\
\text { える影響 }\end{array}$ & 周辺環境に有害な影響を与えない. \\
\hline $\begin{array}{l}\text { 復 } \\
\text { 性 }\end{array}$ & $\begin{array}{l}9 \text { 災害時等の復 } \\
\text { 旧性 }\end{array}$ & $\begin{array}{l}\text { 復旧対策が必要となるような災害時の偶発 } \\
\text { 的な作用を受けた場合でもトンネルが壊 } \\
\text { せず性能回復が容易に行える. }\end{array}$ \\
\hline
\end{tabular}

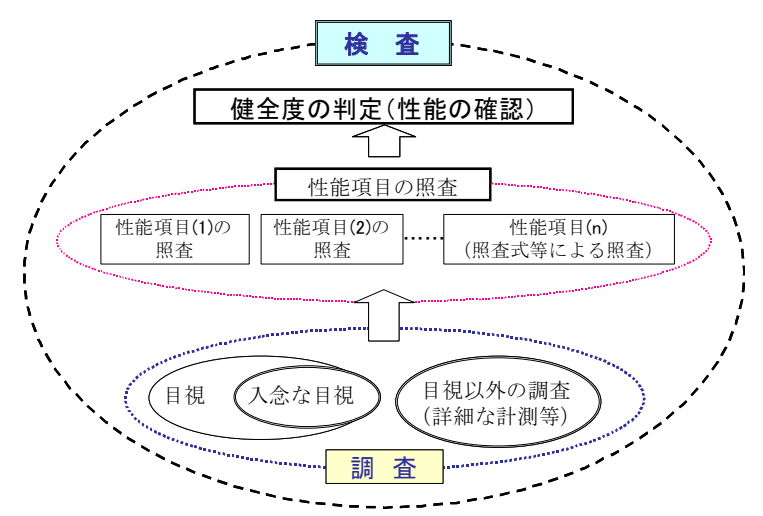

図-3 検査における性能の確認の考え方 ${ }^{3), 4)}$

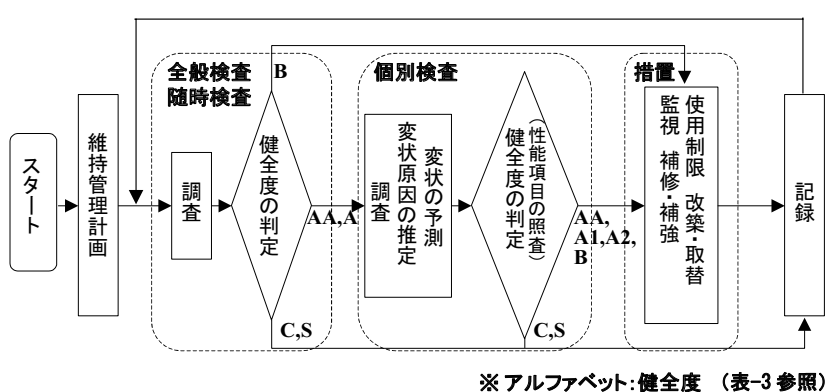

図-4 鉄道構造物の維持管理の流れ 3),4)

ついて取り扱うことにし，また，使用性，復旧性につ いては必要に応じて適宜設定している，実際の維持管 理は，構造物の検査の周期，方法等を定めた維持管理 計画に基づいて，一般に図-3,4 に示す手順で行う。検 查は，初回検査，全般検査（通常全般検査，特別全般 検査)，随時検査に区分され（表-2），全般検査で健全 度の全体把握とともに個別検査や措置の要否を判定す る (表-3).この検査では, 外力・劣化・漏水等による 機能障害に対する検査とともに，トンネルや高架橋で は，はく落に対する検査も行うが，その手順は次のと
表-2 鉄道トンネルにおける検査区分 ${ }^{4)}$

\begin{tabular}{|c|c|}
\hline 検査区分 & 内 \\
\hline 初回検査 & $\begin{array}{l}\text { 初期状態の把握を目的に新設時等の供用開始前 } \\
\text { に実施する検査. 至近距離からの目視と打音. }\end{array}$ \\
\hline 全般検査 & $\begin{array}{l}\text { 健全度の全体把握とともに個別検査や措置の要 } \\
\text { 否を判定するため定期的な検査. }\end{array}$ \\
\hline 通常全般検査 & 2 年ごとに実施. 目視と打音主体. \\
\hline 特別全般検査 & $\begin{array}{l}\text { トンネルでは新幹線 } 10 \text { 年, 在来線 } 20 \text { 年ごとに } \\
\text { 実施. 至近距離からの目視と打音. }\end{array}$ \\
\hline 個別検査 & $\begin{array}{l}\text { 全般検查, 随時検査で「健全度 } \mathrm{A} 」 の \text { 場合に実施 } \\
\text { する検査で, 変状程度および性能の把握, 変状 } \\
\text { 因の推定, 措置の要や時期, 方法等の精查を行 } \\
\text { う. }\end{array}$ \\
\hline 随時検査 & $\begin{array}{l}\text { 地震や大雨等で変状が発生した場合など必要な } \\
\text { 場合に実施. }\end{array}$ \\
\hline
\end{tabular}

表-3 鉄道トンネルにおける健全度判定区分 ${ }^{4)}$

（1）はく落以外の安全性に対する判定

\begin{tabular}{|c|c|c|c|c|}
\hline \multicolumn{2}{|c|}{ 健全度 } & $\begin{array}{l}\text { 運転保安, 旅客お } \\
\text { よび公衆などの安 } \\
\text { 全に対する影響 }\end{array}$ & 変状の程度 & 措置等 \\
\hline \multirow{3}{*}{ A } & AA & 脅かす & 重大 & 緊急に措置 \\
\hline & A1 & $\begin{array}{l}\text { 早晚脅かす. 異常 } \\
\text { 外力の作用時危険 }\end{array}$ & $\begin{array}{l}\text { 進行中の変状等. } \\
\text { 性能低下も進行 }\end{array}$ & 早急に措置 \\
\hline & A2 & 将来脅かす & $\begin{array}{l}\text { 性能低下の恐れが } \\
\text { ある変状等 }\end{array}$ & 必要な時期に措置 \\
\hline \multicolumn{2}{|r|}{ B } & $\begin{array}{l}\text { 進行すれば健全度 } \\
\text { A になる }\end{array}$ & $\begin{array}{l}\text { 進行すれば健全度 } \\
\text { A になる }\end{array}$ & $\begin{array}{l}\text { 必要に応じて監視 } \\
\text { 等の措置 }\end{array}$ \\
\hline \multicolumn{2}{|c|}{$\mathrm{C}$} & 現状では影響なし & 軽微 & $\begin{array}{l}\text { 次回検査時に必要 } \\
\text { に応じて重点的調 } \\
\text { 查 }\end{array}$ \\
\hline \multicolumn{2}{|c|}{$S$} & 影響なし & なし & なし \\
\hline
\end{tabular}

（2）はく落に対する判定

\begin{tabular}{|c|c|}
\hline 健全度 & 変状の状態 \\
\hline$\alpha$ & 近い将来, 安全性を脅かすはく落が生じる恐れがあるもの \\
\hline$\beta$ & $\begin{array}{l}\text { 当面, 安全性を脅かすはく落が生じる恐れがないが, 将来 } \\
\text { 健全度 } \alpha \text { になるのあるの }\end{array}$ \\
\hline$\gamma$ & $\begin{array}{l}\text { 変状が認められるものの, 安全性を脅かすはく落が生じる } \\
\text { 恐れがないもの }\end{array}$ \\
\hline
\end{tabular}

おりである。

1) 全体の目視検査を行った上で必要な箇所の打音 検査を行う。

2) 打音検査で「濁音」が生じる場合は，可能な範囲 で吒き落とす。

3) はく落に対する判定 $(\alpha$ : 要対策, $\beta$ : 要注意, $\gamma$ : 問題なし，の3つに区分されている）を行い， $\alpha$ に判定されたものについてはく落対策工を施す。

\section{4. 健全度診断の自動化}

\section{（1）健全度診断支援のための活動}

鉄道構造物の検査および健全度診断には，多くの経 験と労力および知識を必要とする。しかし, 現場にお ける人員不足, 経験不足, 技術継承の困難さ等から, 診 断結果のバラツキが見られる場合もある。この診断を 
サポートするため，健全度評価の考え方，図表や事例 を鉄道構造物維持管理標準 ・同解説の解説や付属資料 あるいは各種マニュアル，手引き，事例集等に掲載し 出版している.さらに, 具体的な業務を支援するシス テムの開発も行われている。ここでは，このような取 り組みを紹介する。

\section{（2）鋼橋・コンクリート構造物健全度診断支援システ} $4^{5)}$

このシステムは，鋼橋・コンクリート構造物の総合 的な健全度診断システム（図-5）である。測定システ ム, 評価システム，データベースより構成されている (図-6). 全般検査の支援としては，目視検査支援シス テム，ひび割れ記録等の機能があり，携帯型端末を用い た検査の実施や，検査後の結果記録，報告書作成を支 援するほか，過去の検査履歴をリンクしたデータベー スから呼び出すことができる。 また，維持管理標準の 判定基準，過去の同種変状の事例，対策事例なども表 示できる，有効な使い方として，はじめに専門家が一 度全線の踏査を行い, 各橋梁ごとに弱点箇所を把握し たうえで，検査の着目箇所や処方箋を記録したカルテ を作成し，データベース化を図る。そして，それをも
とに現場の検査員が全般検査を行うというもので，検 査の際には検査員が重要な変状を見逃す恐れが少なく なり，安全性の向上が期待できる。

個別検査については，鉄筋かぶり，中性化深さ，塩 化物イオン量などを測定する機器, また, 評価システ ムは, 荷重相当值, 等価繰返し回数等の荷重評価, 中 性化, 塩害の変状予測, 耐荷力の算定などによる構造 物の健全度判定を行うプログラムから構成されている。 特徵は, 実橋測定から耐荷力, 耐久性や走行性などの 定量的診断を一貫して行うことができ，その結果を報 告書の書式で出力できる.

\section{（3）トンネル健全度診断システム ${ }^{6)}$}

トンネルの健全度診断の自動化の研究も進められて いる。このシステムは，撮影画像や電子化された変状 展開図等の検査記録，およびトンネル諸元，地形地質， 構造, 補修履歴等の基本情報を入力することにより, 自 動的に変状を抽出し, 変状の原因推定および健全度診 断ができるシステムである（図-7）。このシステムで, 全般検査の省力化が図れるだけでなく, 変状現象を自 動的に診断することにより，経験の少ない技術者でも既 存の検査データからより精度の高い分析ができる。ま

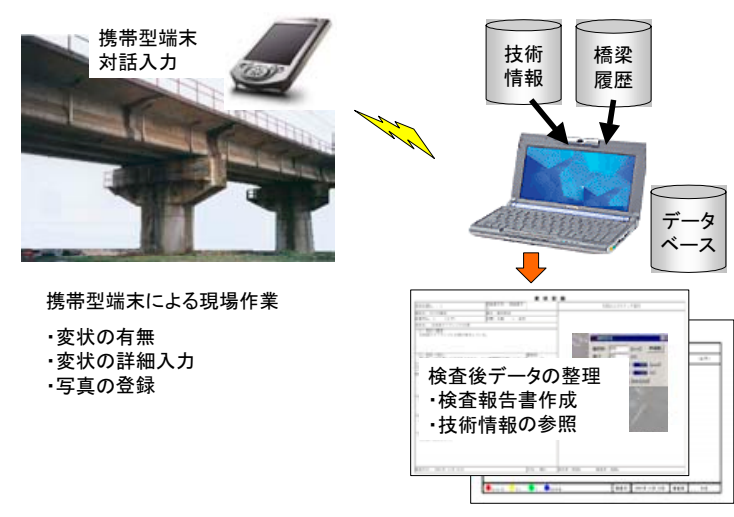

図-5 鋼橋・コンクリート構造物健全度診断支援 システムの概念図 ${ }^{5}$
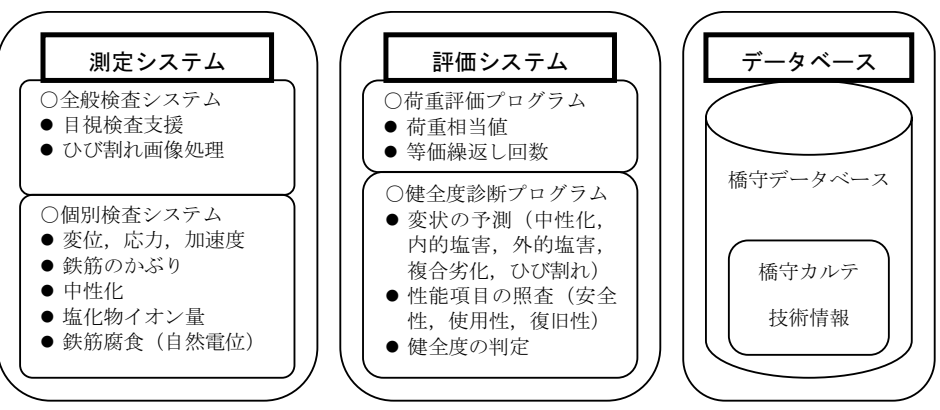

図-6 全体システムの概要 ${ }^{5)}$

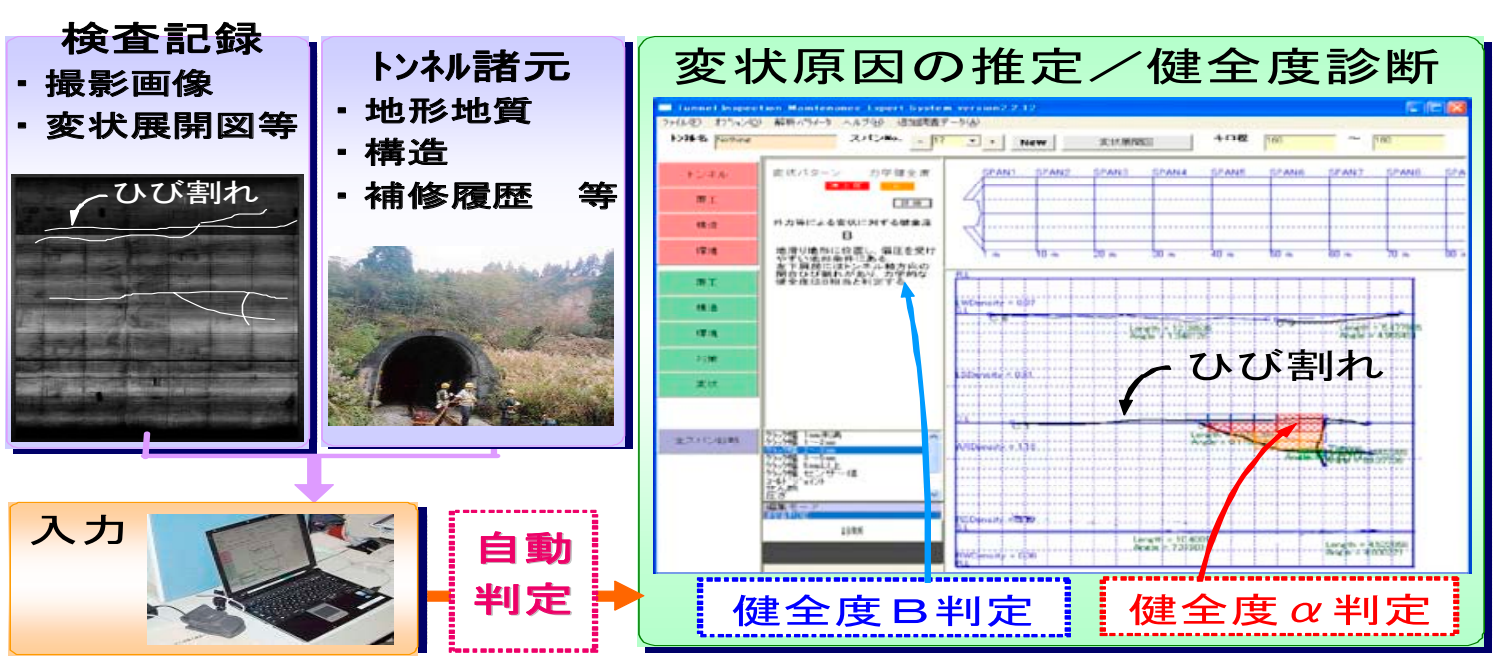

図-7 トンネル健全度診断システム 6 


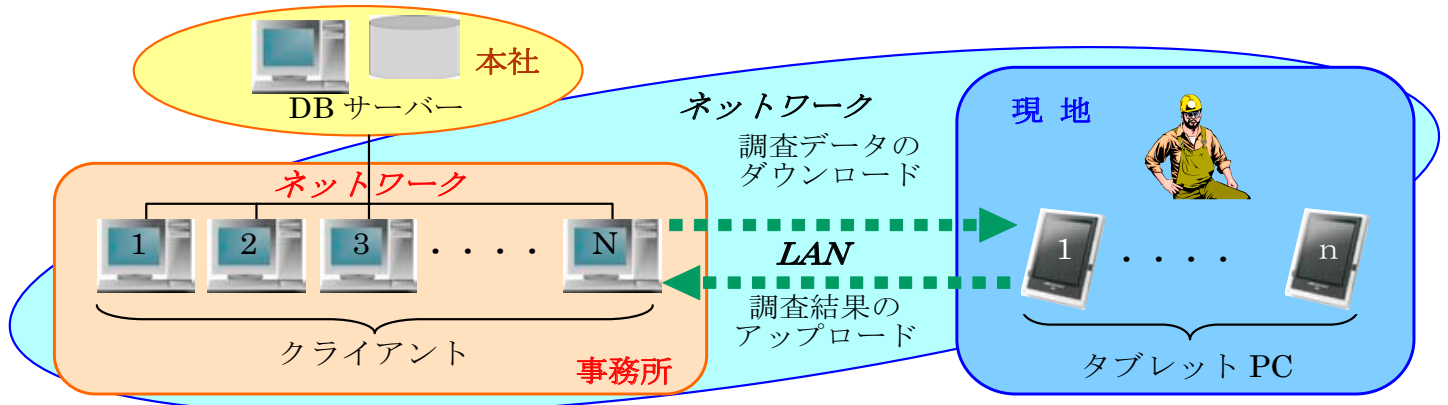

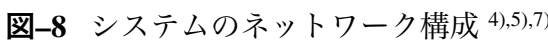

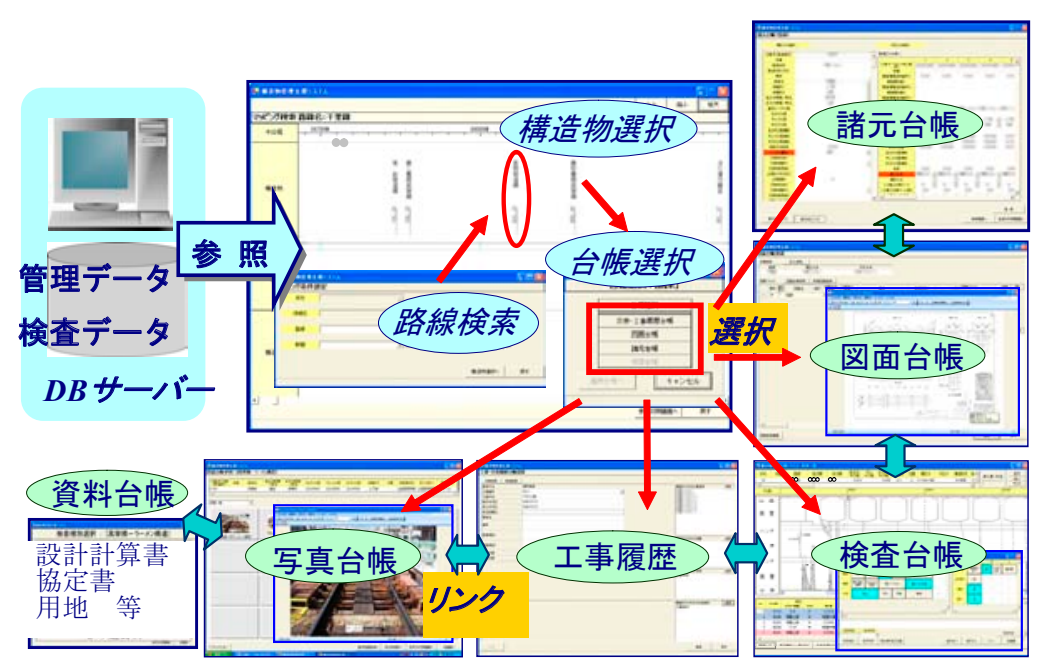

表-4 目安判定マトリクスの入力例 5)

\begin{tabular}{c|c|c|c}
\hline 項目 & 大 & 中 & 小 \\
\hline 規模 & $\begin{array}{c}\text { 幅 } 3 \mathrm{~mm} \\
\text { 以上 }\end{array}$ & $\begin{array}{c}\text { 幅 } 1 \sim \\
3 \mathrm{~mm}\end{array}$ & $\begin{array}{c}\text { 幅 } 0.5 \\
\sim 1 \mathrm{~mm}\end{array}$ \\
\hline 分布 & 併合 & $\begin{array}{c}\text { 平行 } \\
\text { or 交差 }\end{array}$ & 単独 \\
\hline 漏水 & $\begin{array}{c}\text { 連続的に } \\
\text { 流下 }\end{array}$ & $\begin{array}{c}\text { 滴下 } \\
\text { or 法み }\end{array}$ & 漏水なし \\
\hline
\end{tabular}

図-9 データベースシステム 4),5),7)

た, 打音検査装置や光ファイバによるトンネル覆工常 時監視システム等, 最新の検査技術から得られたデー 夕も盛り込んで判定できるょうに構築されている.

\section{（4）鉄道事業者との新たな取り組み（複数の鉄道事業者 が共同開発した構造物維持管理支援システム) 4),5)}

「鉄道構造物等維持管理標準」の制定に合わせて鉄 道総研と全国 14 の鉄道事業者（大手民鉄および公営地 下鉄）が共同で鉄道構造物の検査業務をサポートする 「目安判定機能を持った鉄道構造物維持管理支援システ ム」を開発した。開発にあたってのコンセプトは,

1) 検査の効率的な実施をサポート

2) 検査結果の保管および活用をサポート

3) 検査結果のバラツキを抑制

するシステムの開発である。また，鉄道事業者と鉄道 総研で同じシステムを使い, 共にメンテナンスに関す る勉強を進め，ノウハウ等を共有することやシステム 開発費・維持費を複数の鉄道事業者で按分し，1 社あ たりの費用を軽減することも目的であった。この考え 方をもとに，上記 1）についてはデータベース，事務所 端末，現地端末のネットワーク化（図-8），2）につい てはデータベースシステムの構築（図-9)，3）につい ては健全度の判定補助機能の開発（図-10), を行った。 特に，健全度の判定補助機能は，現場において端末

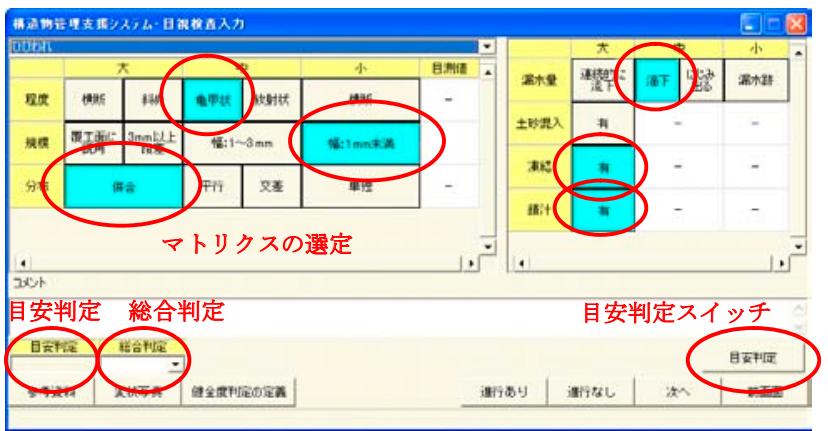

図-10 目安判定マトリクスの入力画面 ${ }^{7)}$

上で変状の位置, 程度, 規模などの情報を $3 \times 3$ の簡単 なマトリクス (表-4) 上で選択すると, 目安の判定が自 動表示される（図-10）もので，これを参考に検査員が 総合判定を下す仕組みになっている，検査時の健全度 判定の考え方が，データとなって残るという利点もあ り，初任者の教育システムとして活用することもでき る。現在，各鉄道事業者で運用が始まるとともに，運 営協議会を立上げ，システム改良の検討やメンテナン ス手法の勉強・情報交換の場として利用している。 ま た，14 事業者以外の鉄道事業者にも参加を広く呼びか けており，運営協議会会員は現在 20 社を超えている. 


\section{5. 検査の機械化}

\section{（1）検査の機械化の目的}

鉄道構造物は, コンクリートのはく離, 鋼材の腐食・ 疲労など様々な変状が発生するほか, 地震, 地盤変位, 雨，環境，衝突，火災等により，性能が低下する。こ れを，通常は，目視主体の定期検査で見極める。しか し, 対象が地中, 高所, トンネル内, 危険箇所等に存在 していたり，被覆されていたりし，直接見ることが困 難な場合が多い。 また，その結果は検査員の経験とセ ンスに依存しているのが実情で，結果にバラツキが見 られる場合もある。これら検査のサポート，検査・診 断精度の向上を目指して新しいセンサやセンサを用い た検査法の研究開発が進められている。代表的なもの を，以下に紹介する。

\section{（2）橋梁下部構造物診断システム ${ }^{8)}$}

地中にある基礎の健全性を直接目で確かめることは 難しいため, 基礎の健全度を判定する方法として「衝撃 振動試験法」（図-11，写真-1）が開発されている。こ の試験では，橋脚や高架橋の天端を重錘で打撃し得ら れる振動応答波形を収録し，フーリエスペクトル解析 を実施し橋脚や高架橋の固有振動数を決定する。そし て，この実測固有振動数と診断基準值である固有振動 数の「標準值」（健全な場合の固有振動数）を比較し健 全度を評価する。また，補強効果の確認にも用いられ ている。この衝撃振動試験は，解析までをサポートす るコンパクトなシステムが開発されてきたが，最近は，
センサとシステム本体のデータの受け渡しを無線化し たシステムが実用化されている。

\section{（3）トンネルの検査システム4),9)}

トンネルの検査で, 従来の目視観察・スケッチにかわ り, 覆工表面の鮮明な映像を連続的に撮影し, 画像処理 による変状展開図の作成や，ひび割れ等の変状の自動 抽出，健全度判定を行う技術が開発されている(表-5).

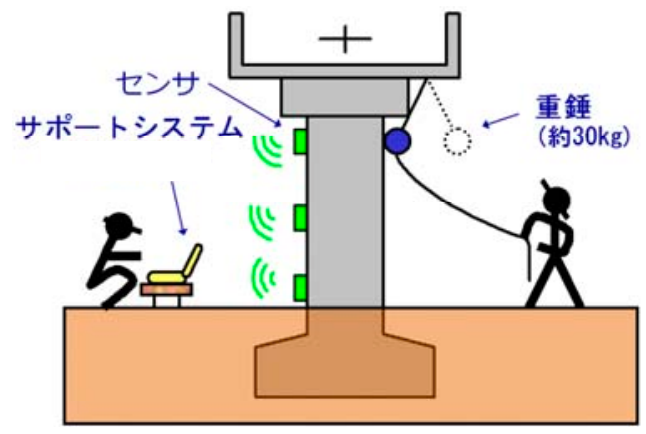

図-11 衝撃振動試験 ${ }^{8)}$

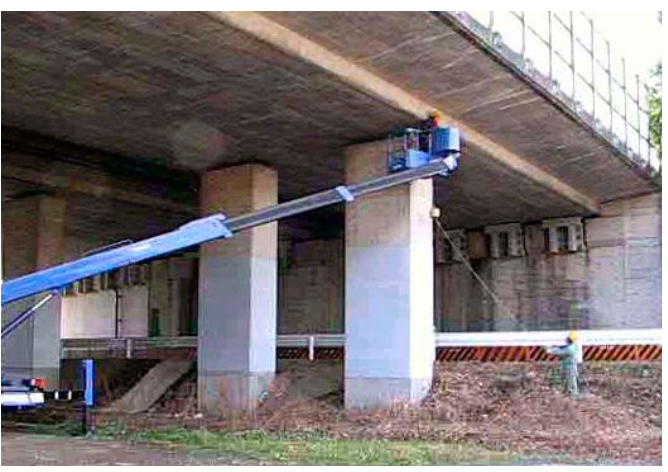

写真-1 衝撃振動試験法実施状況 9)

表-5 覆工表面を連続的に撮影・記録するシステム等の例 4)

\begin{tabular}{|c|c|c|c|}
\hline 手 法 & 概 要 & 主な仕様 & 適用実績 \\
\hline \multirow[t]{3}{*}{$\begin{array}{l}\text { ラインセンサカ } \\
\text { メラ（連続走査 } \\
\text { 画像） }\end{array}$} & \multirow[t]{3}{*}{$\begin{array}{l}\text { 走行しながら壁面を走査して画像を得, } \\
\text { 連続走査画像から展開図を作成 }\end{array}$} & $\begin{array}{l}15 \mathrm{~km} / \mathrm{h} \text { (単線) } \\
27 \mathrm{~km} / \mathrm{h} \text { （複線, 片側） } \\
\text { 幅 } 1 \mathrm{~mm} \text { のクラック検出 }\end{array}$ & $\begin{array}{l}\text { JR 東海（トンネラス） } \\
\text { ・1999 年度から稼動 } \\
\text { ・在来線 }\end{array}$ \\
\hline & & $\begin{array}{l}10 \mathrm{~km} / \mathrm{h} \\
\text { 幅 } 1 \mathrm{~mm} \text { のクラック検出 }\end{array}$ & $\begin{array}{l}\text { JR 北海道 } \\
\text { • } 2002 \text { 年度 稼動 }\end{array}$ \\
\hline & & $\begin{array}{l}10 \mathrm{~km} / \mathrm{h} \text { 程度 } \\
0.5 \sim 1 \mathrm{~mm} \text { の解像度 } \\
※ \text { 上記よりも簡易な撮影システム }\end{array}$ & $\begin{array}{l}\text { 鉄道総研（トンネルスキャナ） } \\
\text { ・2004 年度から稼働 } \\
\text { ・民鉄等 }\end{array}$ \\
\hline \multirow[t]{2}{*}{ レーザー } & \multirow[t]{2}{*}{$\begin{array}{l}\text { レーザービームで全周をスキャニング } \\
\text { し画像処理を施して連続壁面画像を } \\
\text { 得，展開図を作成 }\end{array}$} & $\begin{array}{l}\text { 4〜 } 7 \mathrm{~km} / \mathrm{h} \text { 以下 } \\
\text { 幅 } 0.5 \mathrm{~mm} \text { のクラック検出 }\end{array}$ & $\begin{array}{l}\text { JR 東日本 } \\
\text { • } 2000 \text { 年度から稼働 } \\
\text { ·新幹線, 在来線 }\end{array}$ \\
\hline & & $\begin{array}{l}2.8 \sim 17 \mathrm{~km} / \mathrm{h} \\
\text { 幅 } 0.5 \mathrm{~mm} \text { のクラック検出 }\end{array}$ & $\begin{array}{l}\text { JR 西日本 }(\text { SATUZO) } \\
\text { • } 2001 \text { 年度から稼動 } \\
\text { ・新幹線, 在来線 }\end{array}$ \\
\hline スリットカメラ & $\begin{array}{l}\text { 走行速度とフィルムの送り速度を同調 } \\
\text { したカメラにより連続壁面写真を得る }\end{array}$ & $\begin{array}{l}\text { 30〜 } 40 \mathrm{~km} / \mathrm{h} \\
\text { 幅 } 1 \mathrm{~mm} \text { 以下の解像度 }\end{array}$ & $\begin{array}{l}\text { JR 西日本 } \\
\text { ・1995 1997 年度に神戸支社にて実施 } \\
\text { ・新幹線 }\end{array}$ \\
\hline パノラマカメラ & $\begin{array}{l}\text { パノラマカメラによりトンネル輪切り } \\
\text { 方向に撮影したものを画像処理により } \\
\text { 繋ぎ合せ，連続壁面展開図を作成 }\end{array}$ & $\begin{array}{l}1 \text { 晚で } 1 \mathrm{~km} \\
\text { 幅 } 0.2 \sim 0.3 \mathrm{~mm} \text { のクラックも検出 } \\
\text { 可能 }\end{array}$ & $\begin{array}{l}\text { 近鉄 } \\
\text { ・1991 年度から稼動 }\end{array}$ \\
\hline $\begin{array}{l}\text { マルチパス方式 } \\
\text { レーダー※ }\end{array}$ & $\begin{array}{l}\text { マルチパス方式のレーダーで全周をス } \\
\text { キャニングし, 覆工コンクリートの表 } \\
\text { 面状況と内部状況を } 3 \text { 次元的に捉える. }\end{array}$ & 最高 $3.5 \mathrm{~km} / \mathrm{h}$ & $\begin{array}{l}\text { JR 東日本 } \\
\text { • } 2004 \text { 年度から稼動 } \\
\text { ・新幹線 }\end{array}$ \\
\hline
\end{tabular}

※覆工内部の変状の抽出を主目的とするもの 


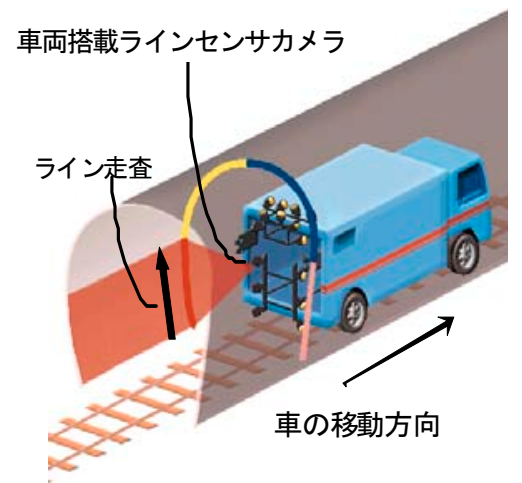

図-12 連続走査画像撮影システム4),9)

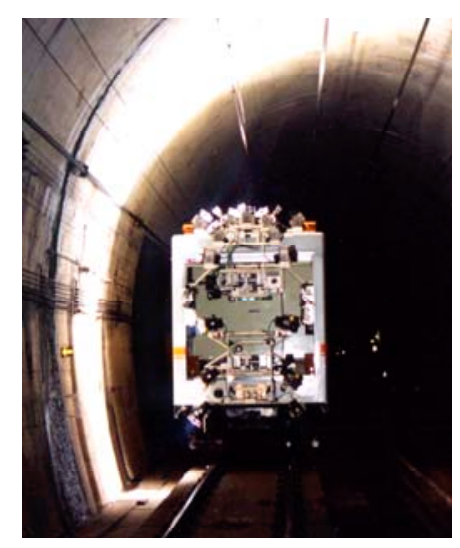

写真-2 連続走查画像撮影装置 ${ }^{4), 9}$

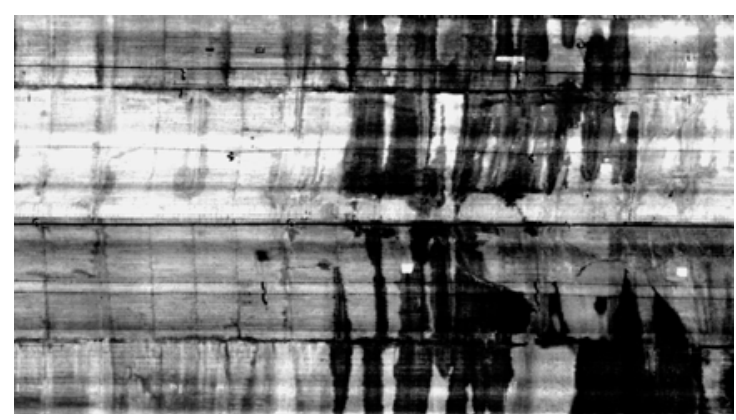

写真-3 覆工展開画像の例 ${ }^{4), 91}$

鉄道総研では，「連続走査画像撮影システム」(図-12, 写真-2）を開発している。このシステムは, 複数台の カメラで分割して撮影したトンネル覆工の画像につい て，ひずみ等を補正して重称わせ，トンネル延長方向 および横断面方向に切れ目のない鮮明な一枚の展開画 像を作成するもので (写真-3), JR 東海と JR 北海道に おいてすでに実用化されている。 また，この撮影シス テムの開発に加え, 変状展開図作成ツールの開発, ひ び割れを抽出する画像処理アルゴリズムの開発・実用 化の研究も行っている.

トンネル覆工の非破壊検査の研究開発も進められて いる，これは，覆工の表面，内部，背面を破壊せずに調 査する方法で, 打撃音法, 超音波法, 弾性波法, 電磁波 法, 熱赤外線法等が開発・実用化されている（表-6）.

表-6 に各方法の適用性を示す．図-13 には，JR 東日

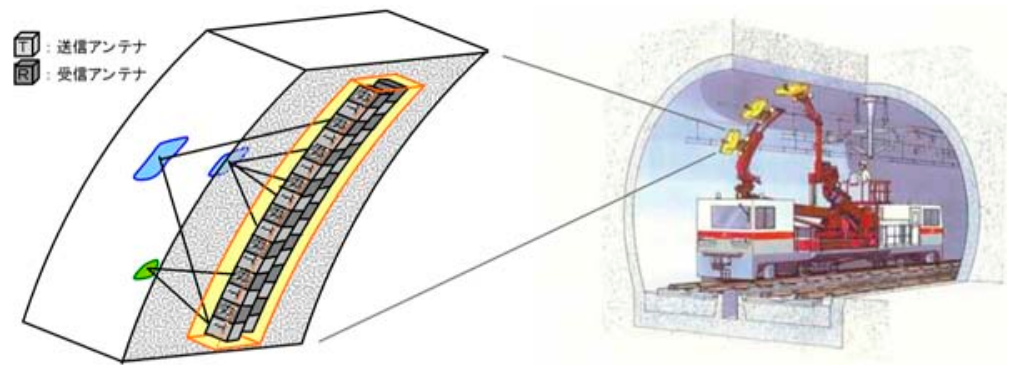

図-13 マルチパス方式レーダ (電磁波) を搭載したトンネル覆工検査車 ${ }^{4)}$

表-6 トンネル覆工の非破壊検査法 ${ }^{4)}$

\begin{tabular}{|c|c|c|c|c|}
\hline \multirow[t]{2}{*}{ 手法 } & \multicolumn{3}{|c|}{ 現在の適用性 } & \multirow[t]{2}{*}{ 調査範囲 } \\
\hline & 表層 & 内部 & 背面 & \\
\hline （1）打撃音法 & 0 & $\triangle$ & $\triangle$ & 点 \\
\hline （2）超音波法 & 0 & O & $\triangle$ & 点 \\
\hline （3）弾性波法 & $\triangle$ & O & $\triangle$ & 点 \\
\hline （4）電磁波法 & $\triangle$ & $\bigcirc$ & () & 線～面 \\
\hline （5）赤外線法 & $\bigcirc$ & $\triangle$ & $\triangle$ & 面 \\
\hline \multicolumn{5}{|c|}{ 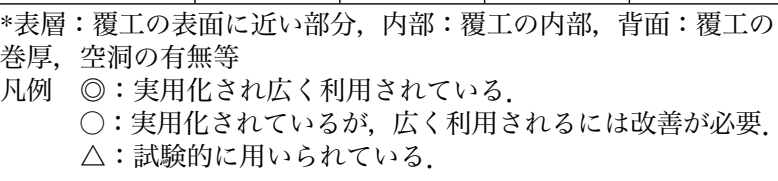 } \\
\hline
\end{tabular}

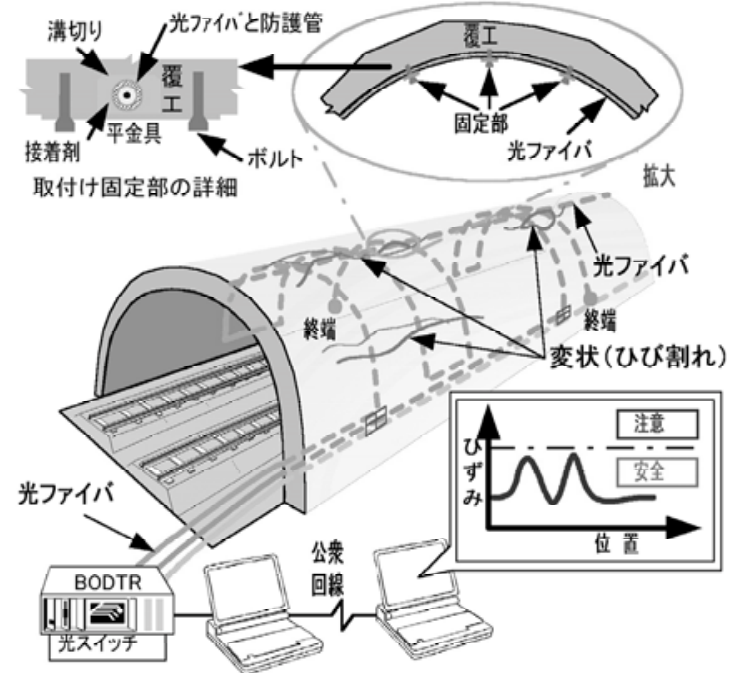

図-14 光ファイバによるトンネル変状監視システムの例 4)

本で実用化されている電磁波法のシステムを示す。

また, トンネル外の遠隔から, 光ファイバや導電塗料 などを利用してトンネル覆工の動きを常時監視する方 法も研究されている．前者は，光ファイバを覆工に貼 り付け，ひずみの発生位置と大きさを長距離にわたつ て計測するものである (図-14)。これにより，トンネ ルのひずみ分布，ひび割れの発生あるいは補強・補修 部分のはく離等がわかる. 後者は覆工に導電塗料を帯 状に塗布し，その両端で通電性をチェックするもので, ひび割れが生じると通電しなくなることを利用した検 知方法である。 


\section{6. モニタリングシステムの研究開発}

\section{（1）モニタリングの目的}

常に計測を行い構造物の方から状態を知らせること ができれば構造物の安全性が向上するとともに, メン テナンスが効率化される。このような，モニタリング システムとしては,

1）損傷の発生あるいは発生した損傷を検知するシ ステム

2) 地震, 洪水や衝突等による異常を発生直後に検知 するシステム

3) 重要構造物を動態監視するシステム

4) 定期点検の省力化のためのシステム が望まれている。これらの要望に対して鉄道事業者で
は，検討が始められているが，鉄道総研でも，ITを積 極的に導入した「構造物へルスモニタリングシステム」 の開発に取り組んでいる(図-15).

\section{（2）異常時モニタリングシステム}

a) $\mathbf{R C}$ ラーメン高架橋損傷レベル検知システム 99,10$)$

現在，地震による高架橋の損傷は被災後に目視で確 認されている。しかし，近年，鋼板巻き補強が行われ， 目視による損傷の把握が困難な柱が増えている。一方, 柱端部に生じる最大応答部材角と損傷レベルの関係が 概ね把握されているため, この部材角を効率的に測定 すれば，地震後早期に柱の損傷レベルを評価すること が可能となり, 復旧作業の効率化や地震発生から列車 運行再開までの時間短縮が図れる。このような背景か

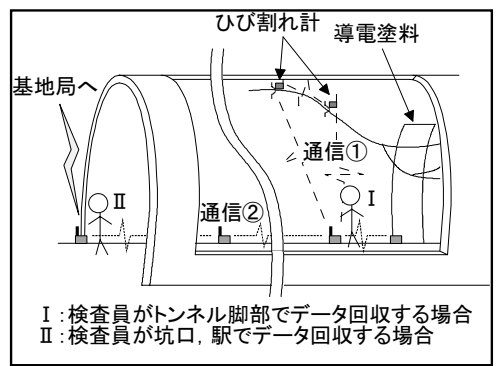

(e) トンネルのシステム

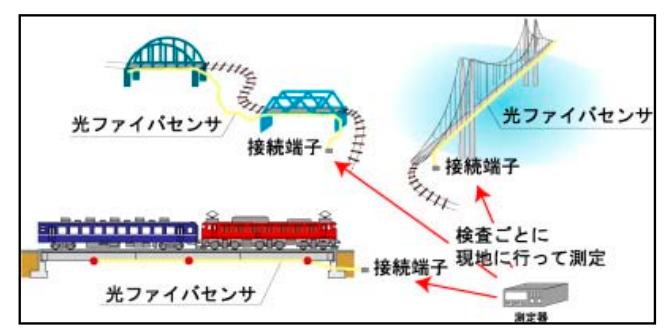

(f) 鋼橋のシステム

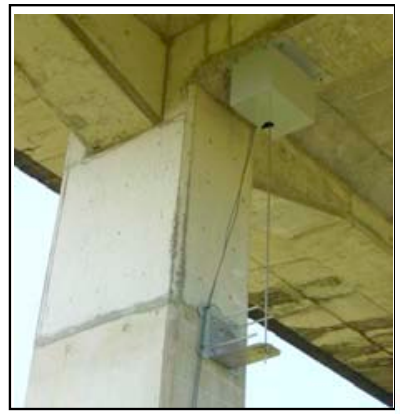

(c) 部材角測定装置 (ピークセンサ)

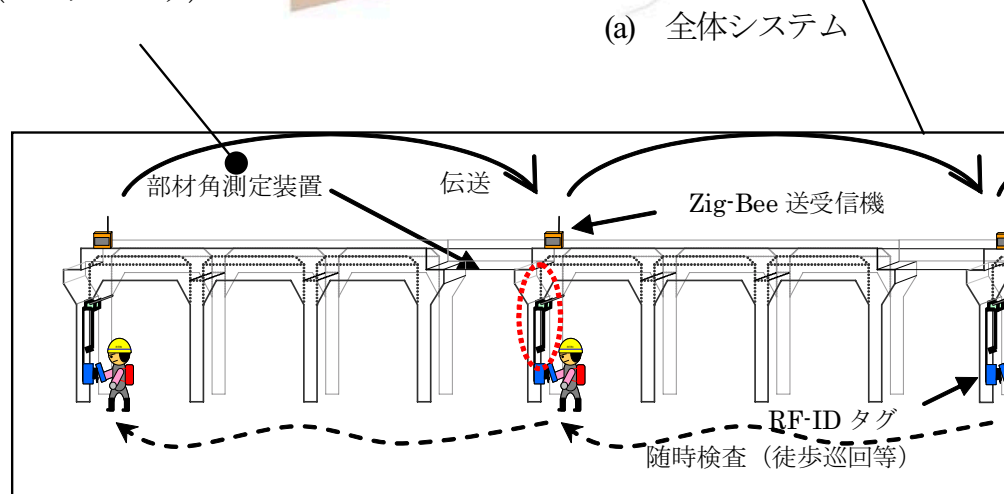

(a) 全体システム
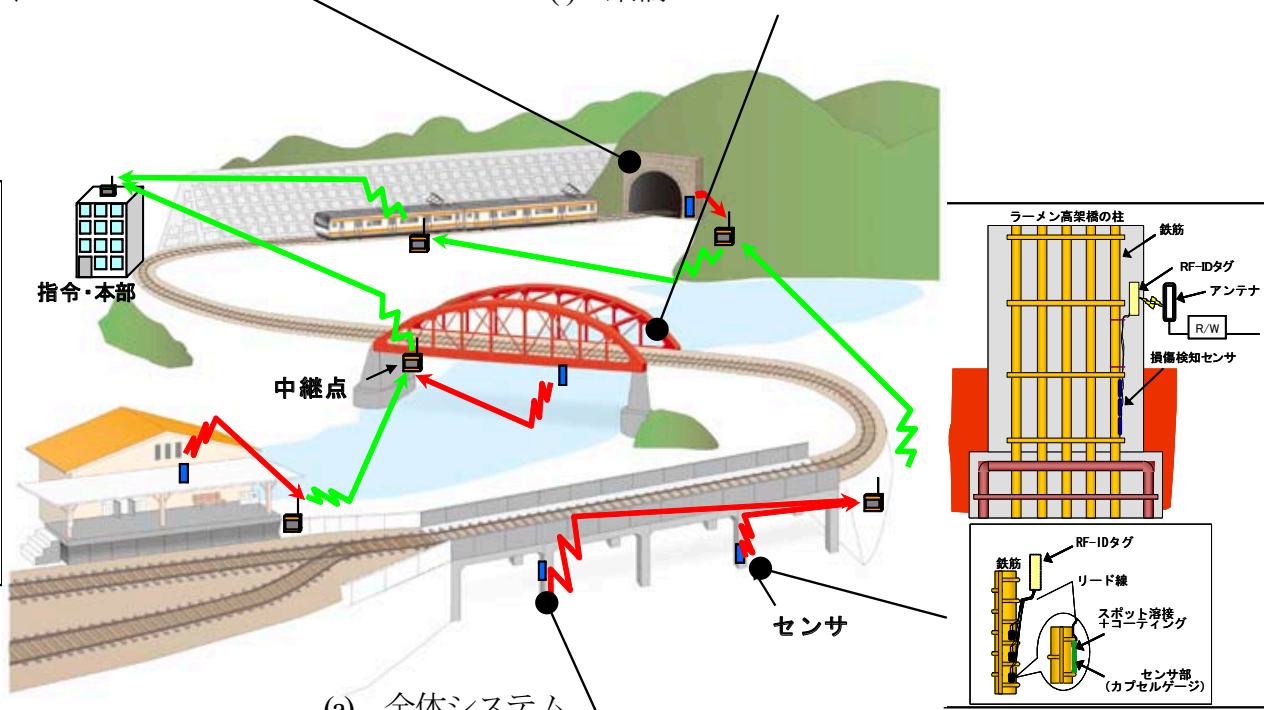

(d) 基礎のシステム

(b) RC 高架橋のシステム

図-15 構造物ヘルスモニタリングシステム ${ }^{9), 10)}$ 
ら，最大応答部材角測定システム（図-15（b)）を開発 した。このシステムでは, 測定装置 (図-15 (c)) を高架 橋柱に設置し, 地震時における線路方向, 線路直角方向 の最大応答部材角を測定する。得られたデー夕は，送 受信機を中継し基地局へ伝送するとともに, 中継器が 損傷した場合は巡回員が RF-ID タグ（Radio Frequency Identification：属性情報を非接触により伝送可能な夕 グ）から直接データを回収することもできる。損傷レ ベル評価の可能性を確認するため，装置単体および実 物大模型柱での静的試験, 振動台による動的試験を行 い, 測定精度を比較した。 その結果, 各試験とも測定 誤差は 7\%程度であり, 精度よく損傷レベルを検知でき ることが確認できた．現在は，この装置を新幹線高架 橋の鋼板巻き補強柱に設置し，耐久性試験を実施して いる.

\section{b）地中部材の損傷自己検知システムの開発9),10)}

地中の柱下端部および基礎の損傷を検知するため,「地 中部材の損傷検知システム」を開発した（図-15 (d)). センサ部は，損傷を確実に検知するため 3 枚のひずみ ゲージで構成し，あらかじめ損傷が発生しやすい部位 の鉄筋に貼り付け，損傷に伴う鉄筋のひずみの大きな 変化を検知するものである，RF-ID 夕グ部は，損傷検 知センサのインターフェースとして，外部より電源供 給を受けた際にひずみゲージの抵抗值を検出し，デー 夕を伝送する。パッシブ方式のためセンサ部の電池交 換等が不要で，RF-ID タグをコンクリートに埋設する ことが可能である。 また，ハンディタイプの R/W (リー ダライタ）を用いることで現場での測定作業を容易に した。

\section{（3）常時モニタリングシステム}

\section{a) トンネルのためのシステム 9 (10)}

トンネルではメンテナンスや近接施工の影響を把握 するために，ひび割れ計や内空変位計により覆工のモ ニタリングが実施される場合がある。しかし，狭隘な トンネルでは計測器の配線が障害になるほか，施工時 の費用, はく離等の安全性の問題も懸念されるため, 無 線通信（図-15 (e)）の適用性を検証している。これは,

1) トンネル坑内の小型計測器間の通信

2) トンネル構内から坑口までの長距離通信

の 2 種類から構築されるものである。現時点では，1） に対応する無線計測器の作成, PC を利用したトンネル 保守台帳とのリンクを中心として開発している ${ }^{9)}$ 。無 線化する計測器は， $\pi$ 型変位計やひず夕計, 導電塗料 で，トンネル保守台帳は, 計測したデータをトンネル覆 工の変状展開図上で可視化できるシステムとした。室 内試験結果では，15 $\mathrm{m}$ の離隔までは途切れることなく 経時計測が可能であることが確認できた。 今後は, 迷 走電流などのトンネル内環境における適用性を確認す
る予定である.

\section{b) 鋼橋のためのシステム 99,10}

鋼橋の疲労き裂の発生を予測するため，従来は電気 式ひずみゲージで応力を測定し累積疲労損傷度（繰返 し応力による鋼材の損傷の指標）を評価している。し かし，足場が必要であることから十数年に 1 回程度し か実施できず，少ない測定データで供用開始から将来 までの疲労を推定することになり，評価の精度が問題 となっていた. 現在開発中のシステムでは, 疲労によ る損傷が問題となる橋梁部材に, 光ファイバセンサを 半永久的に設置し, 応力測定の頻度を増やすことで評 価精度を向上できる（図-15（f））。鉄道橋では列車荷 重や列車の通過本数がある程度既知であり，2 年に 1 度程度の測定を長期間続けることで十分な精度を確保 できる，現在，実橋梁に光ファイバを設置し，センサ の適用性について検討を行っているが，ひずみゲージ と同等の測定精度が得られることを確認している。ま た，得られた応力履歴から累積疲労を算出し，余寿命 等を評価するソフトウェアの開発も行っている.

\section{7. 補修・補強工法の研究開発}

\section{(1) 研究開発の背景}

活線下での補強・補修工事は，限られた空間，限ら れた時間等，様々な制約の中での作業となり，品質確 保が難しく，また，高価なものになってしまう。この ような条件下での効率のよい補修・補強工法の研究開 発も進められている。ここでは, 鉄道総研での研究開 発成果の一部を紹介する。

\section{（2）高性能の吹付け補修工 ${ }^{5}$}

広い範囲に鉄筋の腐食やコンクリートのはく離が生 じた場合，劣化部を除去した後にコンクリートの吹付 け補修を行うが，従来の湿式吹付け工法では吹付け 1 層あたりの最大吹付け厚さが $30 \mathrm{~mm}$ 程度と小さく，付 着強度や施工効率が問題となっていた。そこで，吹付 けノズル先端でアルカリフリー液体急結剤を添加する ことにより，100 mm 程度の吹付け厚さが確保できる 工法を開発した（図-16). 既設コンクリートとの付着 強度については，せん断試験を行い，一体打設の場合

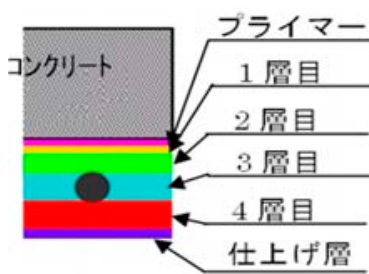

(a) 最大層厚 $30 \mathrm{~mm}$ 程度

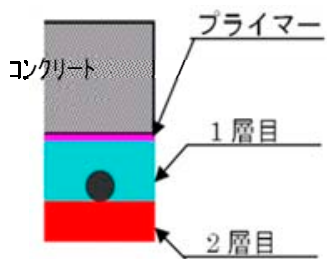

（b）最大層厚 $100 \mathrm{~mm}$ 程度
図-16 従来工法 (a) と新しく開発した工法 (b)の比較例 5) 


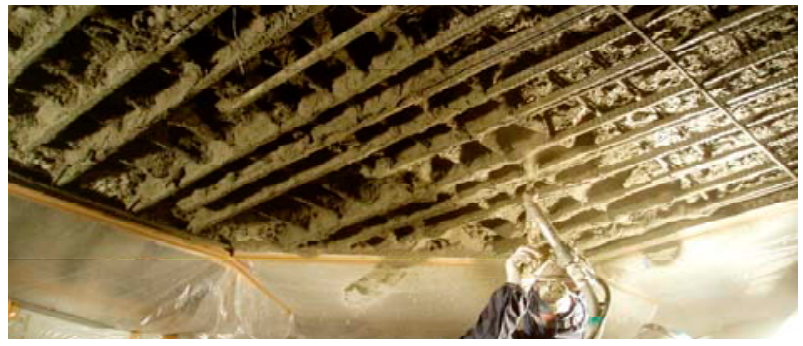

写真-4 高架橋における吹付け補修の状況 5)

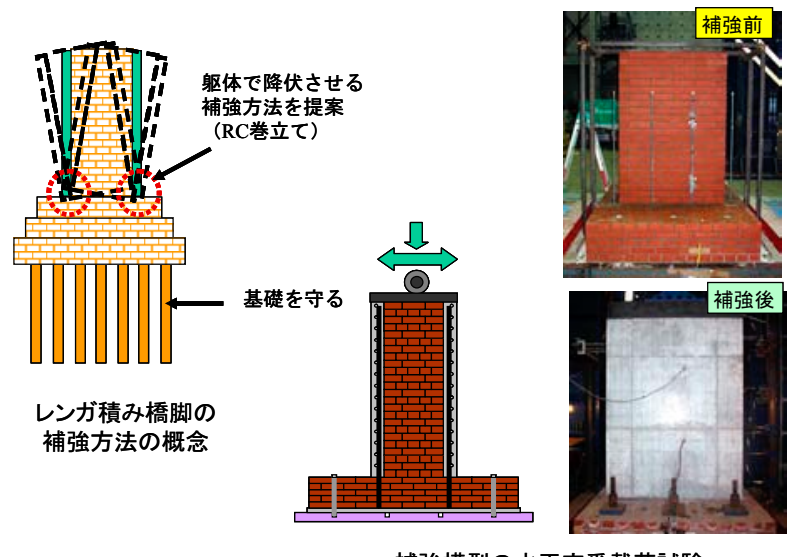

図-17 レンガ積み橋脚の耐震補強方法の提案 ${ }^{5)}$

と同等のせん断強度が得られることを確認した。また， トンネル覆工の補修の場合には, 硫酸塩環境下におけ る耐久性が問題になる場合があるが，浸漬試験の結果 から十分な耐久性を有することを確認した。この工法 は，鉄道高架橋を中心に十数件の現場で実施工されて いる（写真-4）。

\section{（3） 既設構造物の耐震補強 ${ }^{11}$}

兵庫県南部地震以降, 耐震補強の目標が明確にされ, 耐震補強工事が進み既設構造物の耐震性能は次第に向 上しつつある. しかし, 要求される耐震性能のレベル が一気に上がったことから，線区全体で見た場合，

1）明治以降，設計基準，材料等が異なる様々な時代 に建設された数多くの鉄道構造物に対する適切 な評価方法および補強工法の確立

2) 作業空間・作業時間等の様々な制約がある活線下 での効率的な耐震補強工事の開発

3）山岳トンネルの耐震性能評価および補強方法の 研究開発

4) 構造物, 軌道, 電力設備, 車両等様々な設備から 構成される鉄道システムとしてのバランスのよ い耐震設計および補強方法の確立

等の課題があり,これらを解決するための研究開発も 進められている。

鉄道総研では，様々な $\mathrm{RC}$ 橋脚に対する補強工法の 開発とマニュアルの作成, レンガ・石積み構造物の補強 工法（図-17），ポリマー免震工法による開削トンネル
の補強工法, 矢板とタイロッドあるいはラディッシュ アンカー等太径の補強材を用いた盛土の補強工法, 地 盤に恒久注入剂を注入して液状化地盤を改良する方法 の提案等を行っている。 また, 山岳トンネルの耐震設 計法および補強工法の研究や鉄道システムの地震時挙 動を同じレベルで評価・診断し，さらに鉄道線区ある いはネットワークで地震災害によるリスク評価を行い, 鉄道システム全体として最も効率のよい対策を総合的 に判断するための方法論の研究を進めている.

\section{8. 今後の取り組み}

\section{(1) 将来予測 12$)$}

我が国の将来を予測すると，

1) 少子高齢化, 人口の減少

2) 都市への人口集中

3) 環境問題の深刻化

4) 異常気象発生による災害の増加

5) エネルギー資源の枯渴

6) 高度な情報通信網の整備

7) 新技術, 新エネルギーの開発

等が考えられる。これらを参考に鉄道の将来を考える と,

1) 人口が減少し利用客が減るとともに労働力不足 が発生し, 収入が減少しメンテナンス業務の適切 な遂行が難しくなる

2) 都市部への人口の集中がますます激しくなり, 駅 を中心とした都市化が進む

3) 環境問題等から都市を結ぶ鉄道の高速化が図ら れる

4) 老朽化した構造物が増える

5) 災害への早急な対応が必要になる

6) 新技術, 新素材, 新エネルギーの活用が進む 等が挙げられる.

このような予測の中で鉄道構造物のメンテナンスに 関しては，対象となる構造物の数量の増加, 労㗢力・技 術者の不足, 技術力の低下, 技術継承の困難さ等が現 在よりもさらに厳しくなると考えられ，これらの問題 を解決するため, 検査, モニタリング, 健全度評価, 補 修・補強技術に関する研究開発をさらに進める必要が ある。すすおち，より少ない人員で，経験の少ない技 術者でも, 確実でバラツキのないメンテナンスを, 経済 的に行えるようなシステムを構築していく必要がある。

\section{（2）ハード面の取り組み}

将来的には，定期的な検査ではなく，モニタリング による常時監視（状態監視）を行い，ここで得られる デー夕から対象構造物の健全度評価, 性能確認, 将来 
予測を瞬時に行うシステムや，これらのデー夕を利用 して, 維持管理計画, 補修補強計画, 設計へのフィー ドバック等を行うシステムの開発が進められると考え

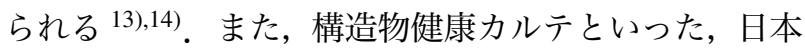
の鉄道の全構造物のデータベースシステムが構築され, 情報バンクなるもので管理し, 利用時の情報提供をす る事業ができると便利になる。これには，デー夕の収 集, 整理, 蓄積, 提供の方法, 以外に, 「価值があるデー 夕は何か？」「これにより誰がどの程度利益を得るの か? 」等を分析し, このシステム運営の方法や, 社会 的な仕組み作り, ルール作り, 資金の確保を検討する ことが必要である ${ }^{15)}$.

構造物そのものについては，モニタリング機能を活 用して自己修復機能を持った構造物の開発が進むであ ろう。また，モニタリングや自己修復機能でも対応で きない事象に対して, 検査や補修ロボットを開発して 対応することも考えられる。

これらを実現するためには，当面は，モニタリング では, 地中やコンクリート内等の透視監視技術, 健全度 評価では，構造物健全度状態予測シミュレーション技 術の開発から進める必要がある。また, 鉄道はシステ ムであるので, 構造物の状態のみではなく, 列車の走 行性までも取り込んだ鉄道システム全体のシミュレー ション技術を精緻な領域まで進めることも必要である.

一方, 基礎的な研究では, 構造物全体系としては崩 壊に至る前の塑性化が始まるくらいまでの研究は進ん でいるが，本当に崩壊する状態までの研究はあまり進 んでいないのが現状である。モニタリングによって得 られた大量のデータから，予想されない突発事故の事 前検知手法やリダンダンシー（呪長性）の評価方法な どの研究も進められるであろう ${ }^{13), 14) .}$

\section{（3）ソフト面の取り組み}

一般市民にとって, 構造物は新規建設のインパクト が大きく, その後何もしなくても安全で, 便利な状態 であるのが普通だと思われがちである，実は，メンテ ナンス担当者の大変な努力のもとに安全・安心で安定 した輸送が成り立っていることは，あまり知られてい ない. 大きな災害や，事故が起こらなければ，地道に 努力しているメンテナンスが必要ないもの, 無駄なも ののように評価されてしまい, メンテナンスの効用を 実感するのは難しい.メンテナンスに関する予算が削 られる, 人員が削減される, 必要性がなかなか顧みら れないのが常である。このようなことから，メンテナ ンス効果の定量化, リスクの可視化の必要性が議論さ れている 13),14). リスク評価によるメンテナンスの効果 の定量化もその解決策の一つである。技術者は，これ らの手法を活用し，鉄道の利用者や技術者以外の事業 者に適切に説明し，施策の意思決定を行っていくこと
が必要である.リスクマネジメントやアセットマネジ メント手法は，こ机ら意思決定する際の参考資料を作 成する手法と考えられる。リスクマネジメント手法を 用いて, リスクの洗い出しや, 補強・補修箇所の優先 順位, 検査方法, 補強・補修方法を検討し, アセットマ ネジメント手法を用いて，メンテナンスに用いる資金 や労働力の確保, 配分計画等を検討するといった, 維 持管理計画法の研究がすでに始められている ${ }^{16)}$. しか し, 将来予測 (不具合事象発生確率) の精度向上, 不 具合事例のデータベース構築, 日常業務とのリンクに よる効率化, 関係者の理解・合意形成等, 解決しなけ ればならない問題が山積みされているのが現状であり, 粘り強く研究を進める必要がある.

一方，メンテナンスに携わる個々の技術者の技術教 育も大切な問題である。現実には, 機器や書物による サポートだけでなく，メンテナンスに従事する技術者 の技術力の維持向上，人員の確保を図っていくことも 必要である。

具体的には,

1）ITを応用した自動判定システム等を用いた教育 システムの構築

2) メンテナンスに関する資格制度の充実

3）現場の技術者と研究者が意見交換をし，一緒に勉 強できるシステムの構築

4）若手技術者とベテラン技術者が意見交換をし，一 緒に勉強できるシステムの構築

等を進めていく必要がある。

ただし，技術伝承の困難さが唱えられているが，た だ昔のことを伝えればよいということでもなく，現在 の形に合った教育が必要である。また， IT 技術を駆使 してメンテナンスのバーチャル体験も利用価值がある と考えられる。このように，八ード面のみの取り組み だけでなく, ソフト面での取り組み, システム化が必 要と考えられる。

\section{9. おわりに}

写真-5 は, 今年で 121 歳になる東海道本線横浜一戸 塚間の清水谷戸トンネル（上り）（1887 年建設） ${ }^{17)}$ で, いまだに現役で活躍している。このように，土木構造 物は適切にメンテナンスすることにより長年にわたり 安全に使用できるものである。昨年 10 月の土木学会誌 において，「土木のもったいないを考える」といった特 集があった ${ }^{18)}$. 私たちも，「もったいない」という気 持ちを忘れず，適切にメンテナンスを行うことにより 構造物が「もつたいない」という状態にならないよう にするべきである．このような安全で信頼される鉄道 を維持していくためには，メンテナンスに関する様々 


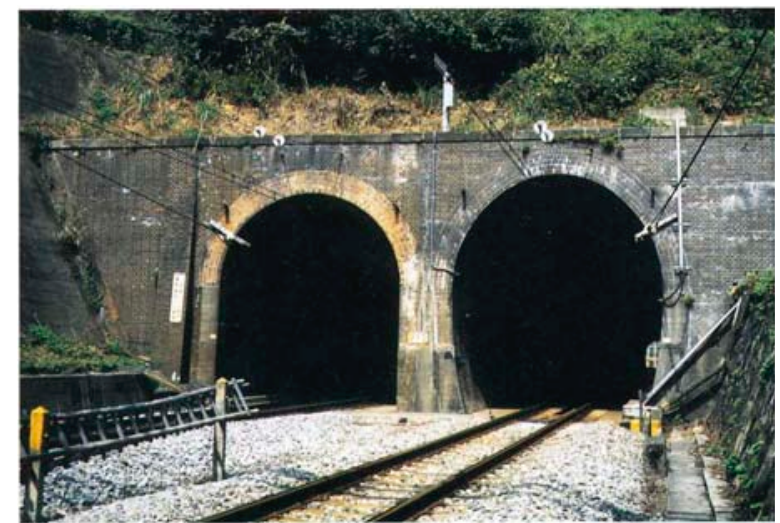

出口方坑門，上り線 1887 年建設（左側）

写真-5 清水谷戸トンネル（東海道本線横浜一戸塚間） ${ }^{17)}$

な角度からの取り組みが必要であり，やらなければい けないことはまだまだたくさんある。精力的に研究開 発を進めていきたい.

\section{参考文献}

1) 市川篤司 : 鉄道構造物等維持管理標準・同解説（維持管 理標準), 平成 18 年度 鉄道総研 鉄道技術推進センター 講演会「維持管理標準の概要と土木構造物・軌道のメン テナンス実務」テキスト，2006.

2) 片寄紀雄 : 最近の災害と対策，JREA，日本鉄道技術協 会, Vol.29, No.9, pp.8-12, 1986.

3）市川篤司：鉄道構造物の新しい維持管理体系，鉄道総研 報告, Vol.19, No.12, pp.1-5, 2005.

4) 国土交通省鉄道局監修, (財)鉄道総合技術研究所編：鉄道 構造物等維持管理標準・同解説 (構造物編)，丸善, 2007.

5) 小西真治, 谷村幸裕: 鉄道構造物のメンテナンスおよび健 全度診断支援システム, 土木技術, Vol.63, No.4, pp.59-64， 2008.

6) 津野究，小島芳之，栗林健一，蒲池秀矢：トンネル健全 度診断システムの開発，平成 16 年度土木学会全国大会 第 59 回年次学術講演会 概要集，6-086, 2004.
7) 小西真治, 菊地誠, 佐藤紀生, 進藤良則, 川浦美佐子, 浅葉喜一，日高直樹 : 鉄道構造物の維持管理支援システ ムの開発〜 14 鉄道事業者による新しい取り組み〜，第 13 回鉄道技術連合シンポジウム講演論文集，No.06-52, pp.195-198, 2006.

8) 小西真治, 仁平達也, 磯野純治 : 構造物の新しい検査技 術，土木技術，Vol.63, No.4, pp.65-71, 2008.

9) 仁平達也, 小林裕介, 峯岸邦行, 磯野純治, 仲山貴司, 山 田聖治, 佐藤紀生, 小西真治: 鉄道構造物におけるへルス モニタリングシステムの開発，検査技術，Vol.12, No.11, pp.15-22, 2007.

10) 鉄道総研 : 鉄道事業者等に利用されている鉄道総研の成 果，鉄道総研， 2007.

11）市川篤司：構造物の耐震性を向上する，平成 18 年度鉄 道総研講演会講演概要集, 2006.

12) 土木学会：線路研究のグランドデザイン, 土木学会構造 工学委員会鉄道構造小委員会「線路研究のグランドデザ イン」研究会 報告書, 2003.

13）藤野陽三 : 社会基盤の災害事故防止に向けたメンテナン スとセンシング技術の活用，平成 19 年度鉄道総研講演 会講演概要集, 2007.

14）藤野陽三：センシングから見た都市空間における安全安 心問題への取り組み, システム/制御/情報, Vol.50, No.10, pp.70-73, 2007.

15）施工中の調査・計測技術に関する検討委員会：大深度地 下利用における地盤および構造物の調査・計測技術，地 盤工学会，ワークショップテキスト， 2002.

16）小西真治, 佐藤豊, 仲山貴司：リスクマネジメント手法 を用いた鉄道トンネル維持管理計画法の検討，第 19 回 秋季信頼性シンポジウム発表報文集, 日本信頼性学会, pp.45-48, 2006.

17) 朝倉俊弘, 小島芳之：トンネルの維持管理, RRR, Vol.51, No.3, 1994.

18）岡本久人：今後の日本の土木一「もったいない」が生じ た後では間に合わない！一特集 土木の「もつたいない」 を考える, 土木学会誌, Vol.92, No.10, pp.27-30, 2007.

(2008. 3. 25 受付)

Maintenance of railway structures in Japan has a wide sphere to cover, because the railway structures have various structural forms of various eras, ranging from the old fashioned style, for example, a structure of over 100 years old, to the latest style, and they have a large variety of types, such as embankment, tunnel, bridge, etc. In around 1965, together with an increase in the disaster prevention investment, the maintenance of railway structures turned from the corrective maintenance system to the efficient maintenance system, combining corrective and preventive maintenance methods. As a result of the turning, accidents were reduced.

However, a large quantity of railway structures, constructed in the period of high economic growth between 1955 and 1973, has been over forty years of age, and a quantity of structures to be taken care of attentively, increased rapidly. This paper presents the history of maintenance, current problems to be solved, and the maintenance standard of railway structure in Japan enacted by the Ministry of Land, Infrastructure and Transport in 2007. Further the present activities for solving the current problems by Railway Technical Research Institute and the railway companies in Japan are introduced, and lastly a prospect of future research and development is described. 